\title{
Kritisere for å forstå? om hermeneutikk og negativ laring i religionsundervisning
}

\section{Av Kåre Fuglseth}

Religionskritikk får stadig større plass $i$ vårt fleirreligiøse samfunn og utfordrar religionsundervisning i skule og kyrkje. Artikkelen drøftar kva plass kritikk kan ha $i$ religionsundervisning ved å sjå på sentrale teoretiske sider ved tilhøvet mellom kritikk og forståing som eit didaktisk grunnproblem. Drøftinga går føre seg på bakgrunn av teoritradisjonar i hermeneutikk, kritisk sosiologi og i danningsdidaktikk. Nokre klassiske, didaktiske problemstillingar og løysingar møter teoriar om kritikk generelt og religionskritikk spesielt. Hermeneutisk teori $i$ Gadamers tradisjon får ein nøkkelfunksjon $i$ teoretiseringar av undervisning og lering. Kritikk kjem i mange former, men har to hovudformer, som skiljande (vid tyding) og dømmande (trong tyding). Den scerlege loeringsverdien av kritiske spørsmål $i$ trong tyding er knytt til rolla åt «negativ» erfaring, for loering er alltid omlæering. Religionskritikk må ein til sist sjå $i$ lys av måla for undervisninga og ut frå danningsmål som både er absolutte og relative eller lukka og opne. Artikkelen konkluderer med at nokre former for kritikk ikkje er eigna i ein slik fleirkulturell didaktikk.

Nøkkelord: didaktikk, hermeneutikk, forståing, kritikk, religionskritikk, danning.

Kåre Fuglseth, f. 1959, professor i fagdidaktikk, Fakultet for loerarutdanning, og kunst og kulturfag, Nord universitet, Pb.1490,8049 Bodø. kare.s.fuglseth@nord.no

\section{KRITIKK SOM MEIR ENN LERINGSMOTIVASJON?}

I dei fleirkulturelle samfunna er det større direkte kontaktflate mellom religionar og livssyn enn nokon gong før i historia. Men det typiske med den fleirkulturelle situasjonen i dag er ikkje berre at han er fleirreligiøs. Situasjonen er spesiell på den måten at han er fleirreligiøs og sekulær samstundes, noko Peter Berger (2014) treffande kallar for dobbeltmangfald («double plurality»). Vi finn dette dobbeltmangfaldet ikkje berre i vestlege land, men så å seie overalt; han er vorte eit verdsomspennande fenomen. Dobbeltmangfaldet gjer kritikk meir aktuelt og utfordrar all religionsundervisning. Vi er i ein situasjon som kan kallast dominerande kritisk: Alle må forsvare seg og rettferdiggjere eigne posisjonar i møte med andre religionar og livssyn, òg dei som vil vere nøytrale. Den tyske pedagogen Dietrich Benner (2008, s. 58ff) kallar dette for ei pluralisering av kritikk.

Denne fleirkulturelle situasjonen har i seg sjølv ein stor læringsverdi. Dette er for så vidt ikkje ein ny påstand. Den mangfaldige situasjonen i skulen og heile 
det fleirkulturelle samfunnet er eit fint høve til å lære om religion, som Friedrich Schweitzer (2014) peikar på. Kritikk kan vere læringsmotivasjon. Men det er gode grunnar til å seie at kritikk av religionar og livssyn i denne situasjonen spelar ei heilt sentral rolle, og det er dette artikkelen skal handle om: kritikk som nødvendig for læring. Men kritikk kan ta mange former, og dei ulike formene vil som vi skal sjå, ha ulik verdi i undervisning, det vere i skule eller i kyrkje. Vi treng først ei kartlegging av desse formene, noko eg skal gjere i tre steg.

Det første steget gjeld kva plass kritisk teori har i lys av hermeneutisk teori eller allmenn forståingsteori. Det andre steget gjeld skilnaden mellom vide og tronge meiningar av orda forståing og kritikk, noko som er avgjerande for den didaktiske vurderinga av den plassen kritikk kan ha. Kartlegginga av desse ulike tydingane av kritikk blir så løfta inn i teoriar om læring som negativ læring. Til slutt skal eg som det tredje steget drøfte kritikk i lys av ein open eller ikkjestadfestande danningsteori som grunnlag for eit fagsyn. Drøftinga gjeld både KRLE-faget og trusopplæringa åt Den norske kyrkja. Døma vil av den grunn bli avgrensa til dei emna planane i skule og kyrkje har til felles, men dei prinsipielle problema og løysinga gjeld uavhengig av kva for kontekst vi arbeider i.

\section{KRITISK TEORI I LYS AV HERMENEUTISK TEORI}

Vi kan ikkje drøfte kritikk generelt eller i religionsundervisning spesielt utan å trekkje inn diskusjonen om hermeneutikk som forståingsteori. Desse heng tett i hop.

Eit sentralt og framleis aktuelt ordskifte om tilhøvet mellom kritikk og hermeneutikk gjekk føre seg mellom tyske filosofar, sosiologar og pedagogar på 1970-talet då representantar for den kritiske teorien i sosiologien (Frankfurtskulen) sette søkjelyset på teoriar om hermeneutikk og danning. Det som har interesse i denne samanhengen, er i første rekke diskusjonane mellom Gadamer, Habermas og Klafki.

Hermeneutikken slik han vart formulert av Gadamer (1990; 2010), forklarer premiss for forståing i og for seg. For å forstå, må vi på ein måte engasjere oss sjølve, sa Gadamer. Alle menneske og menneskelege uttrykk har horisontar som grunnlag for meining eller tydingar, og horisontomgrepet er sentralt i diskusjonen òg om kritikk (jf. òg nedanfor). Førestellinga og metaforen «horisont» er velkjend frå daglegtalen, både i konkret og overført tyding, men det er òg ein naturvitskapleg term som viser til punktet der himmel møter jord eller hav og liknande (i geografi og astronomi særleg). Ordet kjem frå gresk og kan omsetjast med deleline. Horisonten deler til dømes himmel og hav i synsranda. Alle har vi ulike horisontar, men alle har vi faktisk noko vi kan kalle horisont. Det er det at vi har horisontar, som er universelt, og som gjer at vi forstår, og forstår stadig nye ting ved å utvide horisonten. Ein horisont er subjektivt definert, men han er 
ikkje berre personleg eller individuell. I sosiale fellesskap smeltar dei individuelle horisontane saman og blir felleshorisontar. Vi skapar kollektive horisontar, omskapar og tolkar dei sosialt og blir skapte av dei i neste omgang. Vi konstituerer og blir konstituerte i historiske, kulturelle, sosiale og intersubjektive prosessar i ein jamn straum.

Men teorien åt Gadamer møtte motbør av i hovudsak tre typar, som Gallagher (1992) peikar på. Kritikken kom frå:

1 konservativ hermeneutikk,

2 radikal og dekonstruktiv hermeneutikk og

3 kritisk hermeneutikk.

Den konservative lina (1) argumenterte for at humanvitskapen og tekstvitskapane eller filologien trass alt måtte ha ein metode, og at det gjennom ein slik metode var mogleg å kome fram til ei sann innsikt om tekstane (jf. Betti 1967), i alle fall sann «inntil vidare». Gadamer var ikkje motstandar av å utvikle disiplinær metodikk, hovudverket hans heiter trass alt «Sanning og metode», ikkje «Sanning eller metode». Tilhøvet til den radikale, dekonstruktive og postmoderne utfordringa (2) krev ei større utgreiing enn det eg har plass til her. Gallaghers konklusjon på dette området seier at posisjonen er inkonsistent. ${ }^{1}$ Gadamer brukar mykje plass på konkrete bruksmåtar av problemet, mellom det å forstå og det å forklare (1990, s. 312), men i denne samanhengen er det tilhøvet hans til den kritiske hermeneutikken (3) som er mest relevant.

Gadamers universelle argument vart av den kritiske hermeneutikken og kritisk sosiologi ikkje oppfatta som ein allmenn og nøytral teori. Desse meinte at Gadamers løysing var for deskriptiv og politisk passiv. Dette vart hovudstridsspørsmålet, og dei som stilte slike grunnleggjande spørsmål, var mellom anna Karl-Otto Apel og Jürgen Habermas (jf. Apel 1971; Habermas 1971; sjå Apel og $\emptyset$ fsti 2008). Det var særleg dette at forståing er avhengig av tradisjonar, som fall dei kritiske sosiologane tungt for brystet, noko dei såg på som uttrykk for ei konservativ politisk tenking. Innanfor samfunnsvitskapane verkar det som om denne tolkinga har festa seg, slik at det i dag faktisk er mogleg å skrive innføringsb $\varnothing$ ker om tekstanalyse for samfunnsvitarar utan å referere til denne diskusjonen (sjå Bratberg 2017).

Representantane for den kritiske teorien gjekk på same tid òg til åtak på det dei meinte var konservative politiske tendensar i den dominerande tyske pedagogikken og danningsdidaktikken. Den leiande didaktikaren, Wolfgang Klafki,

1 Den radikale hermeneutikken er inkonsistent ved at han kan til sist ikkje grunngje seg sjølv, dvs. relativismen kan ikkje sjølv vere relativ. Diskusjonen mellom moderne og postmoderne kritikk kan vi føre attende til Kant og reaksjonane på hans kritiske filosofi (jf. Critchley 2001, s. 23). Utgreiingar om «mot til å fortelje sanninga» (parrhesi) er ein annan interessant del av denne diskusjonen som eg heller ikkje kan trekkje fram her (jf. Foucault 2013). 
godtok kritikken og etablerte etter dette det han kalla den kritisk-konstruktive didaktikken (jf. Klafki 2002). Skulen skal danne menneske i tråd med dei tre hovudideala: sjølvbestemming, medbestemming og solidaritet, meinte Klafki. Dette er hovudkategoriane i det han kalla kategorial danning. Han kunne relativt uproblematisk føre kritikken frå sosiologane inn i den danningsteorien han alt hadde skipa, dette var berre ein ekstra dimensjon med kategoriar ein måtte trekkje inn som samfunnsdimensjon i danningsidealet.

Så enkelt var det ikkje for Gadamer. Han peika på at teoriane hans låg på eit anna teoretisk nivå enn det dei kritiske sosiologane og danningspedagogane dreiv med. Såleis meinte han (Gadamer 1971) at kritikk alltid føreset forståing, og at kritikarane hadde blanda det førteoretiske og det teoretiske nivået i analysen. Det er alt noko ein har forstått når ein kritiserer. For Gadamer var og vart forståingsteori ein universell teori (1990, s. 478ff) på line med andre fenomenologiske innsikter (1990, s. 245). «Hermeneutikk er forståingskunst», seier Gadamer (1971, s. 283, mi utheving), dvs. noko som unndrar seg forklaringar, men det er likevel mogleg å seie noko om kva det er.

Det universelle ved teorien viser seg òg i naturvitskaplege studiar. Naturvitskapsforskarar tolkar dei òg, men objektet i det naturvitskaplege feltet tolkar ikkje seg sjølv, det er ikkje sjølv refleksivt. Det tyder at meining og menneskelege bruksmåtar - og såleis kultur - blir abstrahert bort i naturvitskap og andre positivistiske tilnærmingar (Seebohm 2004, s. 153), noko som ikkje er gale i og for seg. Slik er det ikkje i humaniora og samfunnsfag. Før nokon kan skjøne kva religionskritikken frå 1800-talet (jf. Hellesnes 2014) eller nyateismen (Dawkins 2008) går ut på, må ein vite kva religion er eller kva desse legg $\mathrm{i}$ ordet religion. Det er forståing som er grunnlaget, og kritikk som er grunnlagt. Eit fleirtal av forskarar verkar no òg bruke hermeneutikk i denne vide tydinga (Porter og Robinson 2011, s. 297). Vi kan snakke om hermeneutikk i trong tyding når ordet dekkjer teksttolkingar og berre tred inn når det er snakk om tolkingar av vanskelege tekstar eller tekstutsnitt (Føllesdal og Walløe 2000, s. 93, jf. $\emptyset$ fsti 1980). I den vide tydinga vert hermeneutikk ein teori om kva som skjer når meining blir til.

Den vide tydinga av hermeneutikk gjer hermeneutikk til ein elementærteori for studiet av menneskeleg verksemd og kommunikasjon og noko vi finn att i dei grunnleggjande vitskapsteoriane for humaniora og samfunnsvitskap. Ein liknande tese om tolking og meining som grunnkategori i livet og i forsking finn vi i sosialfilosofien. I livsverda eller den naturlege innstillinga til livet er meining «klistra» til handling og den sosiale verda, som Alfred Schütz sa det (Schütz 1932, jf. Staudigl 2008). ${ }^{2}$ Forståing, meining og tolking er dei grunnleggjande

2 Alfred Schütz brukte òg Husserls fenomenologi på denne måten til å gje både den forståande sosiologien frå Max Weber og den amerikanske pragmatikken eit teorifundament (jf. Hitzler, Reichertz og Schröer 2003; Apel 1992). 
omgrepa som både samfunnsvitskapen og humaniora byggjer på. Difor får det allmenne spørsmålet om tilhøvet mellom kritikk og forståing òg ein pedagogisk eller didaktisk variant. Danningsteoretikarar som Klafki slepper ikkje unna utfordringa frå denne grunnhermeneutikken. Skal vi i skulen arbeide med kritikk av sosiale tilhøve i samfunnet, føreset det at ein veit kva desse tilhøve er, og di meir ein veit om det, di betre. Dette gjeld ikkje berre i spørsmål om religionar og livssyn, men i alle samfunnsspørsmål eller kulturspørsmål, og det blir særleg tydeleg der dei krev vurderingar. Ved å starte med kritikk av eit fenomen når du skal introdusere det, blir fenomenet lett uforståeleg. Emnet for kritikken kan ikkje vere heilt uintrodusert. Overført på teoriar om kommunikasjon og læring, kan ein seie at det å ikkje forstå er verre enn å misforstå, for når du misforstår, har du trass alt forstått noko og kan byggje på det, sjølv om det viser seg å vere feil. Ut frå denne teorien om hermeneutikk kan ein seie at å misforstå skjer med ein horisont sjølv om ho viser seg å vere ei misforståing, medan det å ikkje forstå er å stå utan slik horisont. Ein står då utan den nødvendige fordommen som gjer ei eller anna forståing mogleg, og såleis òg kritikk mogleg. ${ }^{3}$

Men ei avklaring av kritikkens plass i diskusjonen om undervisning i teori og praksis er ikkje over ved å peike på at kritikk er underlagt hermeneutikk i vid tyding. Også med omsyn til kritikk kan vi snakke om vide og tronge tydingar. Om vi ikkje skil desse to frå kvarandre, blir konkrete analysar av læreplanar og lærarpraksisar lett forvirrande.

\section{KRITIKK I TRONGE OG VIDE TYDINGAR SOM N $\emptyset$ KKEL}

Det å «kritisere», «kritikk» og å «forstå» eller «forståing» er ord vi brukar i daglegtalen rimeleg uproblematisk. Vi brukar «å skjøne» eller «å forstå» både om å kjenne til, skjøne samanhengen og kva nokon har skrive, sagt eller gjort. $\AA$ kritisere vil i dei fleste tilfelle i daglegtalen vere å seie noko negativt om noko eller nokon, å felle ein dom. Vi kan seie «det var stygt sagt» eller «han er dum som gjer noko slikt». Når vi brukar ordet kritikk om slike domsutsegn, kan vi kalle det kritikk i trong tyding. Men det ligg meir i det å kritisere enn slike domsutsegn. For i daglegtalen brukar vi òg «kritikk» i ei meir overordna eller vid tyding. Har vi vore på ein konsert, kan vi lese om konserten etterpå og sjå om kritikken var god, dårleg eller sånn passe kanskje. Uttrykket «ein god kritikk» viser då til ei tyding av ordet der vi ikkje nødvendigvis er negative.

Etymologiske forklaringar av hermeneutikk og kritikk får fram den vide og den tronge tydinga av begge orda. Det greske opphavet til ordet hermeneutikk (hermenevein) tyder både å omsetje og å forklare, og vart særleg knytt til tekst-

3 Fleire slike pedagogiske moment ved dei prinsipielle diskusjonane hjå Gadamers Sanning og metode (1990) er ført vidare i pedagogisk teori generelt (jf. Gallagher 1992; Rittelmeyer og Parmentier 2001) og i religionsundervisning spesielt (jf. Benner, Göstemeyer og Sladek 1999). Om kritikkens plass i pedagogikk meir generelt, sjå Kubac (2013). 
tolking, t.d. av vanskelege og ulogiske avsnitt hos Homer og, seinare, i Bibelen. Det greske opphavet bak verbet å kritisere (krinein) tyder å skilje eller velje ut, og det heng saman med ordet kriterium. Vi treng alltid eit skiljeteikn, eit kriterium, for å skilje noko ut frå noko anna, til dømes klinten frå kveiten. Vi vil kanskje ha klinten bort frå resten av kornet fordi det blir betre å lage mjøl og ete maten då. Rasjonell, positivistisk fornuft blir framleis brukt som kriterium for religionskritikk, slik som hjå Dawkins (jf. 2008), og ateismen forstått på denne måten er ein type positivisme. Den overordna og vide tydinga av ordet kritikk er nærast synonym med eit anna ord for å skilje, nemleg å analysere (å dele opp, frå ana og lyein). Vi brukar altså ordet analyse om lag som i den vide tydinga av kritikk $\mathrm{i}$ dag, jf. Kants kritikkar av fornuft, dømmekraft og praksis, som jo er det vi i dag oppfattar som analysar av desse fenomena. Men kritikk kjem òg til oss frå gresk med negative tydingar, som i skulding og åtak.

Om vi ikkje kunne tolke reint allment (vid tyding), kunne vi ikkje tolke tekstar (trong tyding). Den tronge tydinga byggjer såleis på den vide. Om vi ikkje kunne kritisere i tydinga å skilje (vid tyding), kunne vi heller ikkje dømme (trong tyding). Å kritisere er på denne måten både ein skildrande og ein dømmande dugleik. Den skiljande tydinga føreset at to ting er ulike. Den dømmande tydinga føreset at noko kunne ha vore annleis mellom to eller fleire utskilde element. $\AA$ d $\emptyset$ mme kan i tillegg vere positiv eller negativ, dvs. vi kan like eller ikkje like noko, slik kritikken av gårdagens konsert. Den skildrande dømminga er såleis nøytral på den måten at vi ikkje tek stilling til om konserten var bra eller ikkje (dette blir ofte litt keisamt). I eit større verdiperspektiv er ikkje dette nøytralt, men vi kjem heller ikkje med ein eintydig verdidom. Det er skilnad mellom verdifridom og det å vere verdidomfri. A vere negativt kritisk dømmande til kritikk generelt er ulogisk, då bit ein seg sjølv i halen (jf. Seebohm 2004). Dette viser at kritikk i vid meining òg er noko universelt.

Vi tenkjer som regel på kritikk som ein teoretisk eller kognitiv disiplin, noko vi tenkjer oss til. Men vi kan òg sjå på kritikk som ei handling. Ein lærar handlar til dømes kritisk i trong tyding når ho vurderer ein prestasjon. Vi kan handle kritisk utan å vite om det, individuelt eller kollektivt, anten noko vi gjer eller noko vi let vere å gjere. Eg kan kritisere meg sjølv og den gruppa eg er med i (til dømes lærarar), og eg kan kritisere andre enkeltpersonar eg møter og den gruppa dei tilhøyrer (til dømes rektorar). Profetane i det gamle Israel dreiv indre kritikk av tempelkultusen i Jerusalem, politikarar i same parti kan kritisere partifeller, og religionspedagogar som driv med KRLE-undervisning kan kritisere kvarandre (kor lurt slik intern strid er i møte med grupper bak andre skulefag, er ei anna sak). Vi kan skildre både den indre og den ytre kritikken og i etterkant felle dommar over skildringane. Denne skildringa og dommen over henne i neste omgang kan ein gjere med perspektiv innafrå og utanfrå og på bakgrunn av 
innvendige og utvendige vilkår (jf. Fuglseth 2016). Vi kan vidare kritisere sterkt eller svakt, til dømes både med omsyn til intensitet og til omfang, dvs. kor mange timar brukar vi på det. Alt dette er tilhøve ved kritikk som får didaktiske konsekvensar, og vi finn dei att i læreplanar.

Både i læreplanen for grunnskulen og i trusopplæringsplanen for Den norske kyrkja er kritikk med, og han legg både generelle og konkrete føringar for undervisninga og læringsarbeidet. KRLE-planen (2015) nemner kritikk i trong tyding éin gong i samband med læringsutbyteskildringane: «eleven skal kunne presentere eksempler på religionskritikk fra ulike livssynstradisjoner» (s. 9). Ein kunne tenkje seg at ordet «forklare» hadde noko med kritikk i trong tyding å gjere, av di det ligg rasjonalisering i ordet. Men i læreplanen blir «forklaring» gjerne brukt om det å kunne leggje ut om noko, altså i vid tyding. Det heiter i samband med livssyn at elevene skal kunne «forklare hva livssyn er» (s. 9). Om grunnleggjande dugleikar heiter det at å «uttrykke seg muntlig i KRLE innebærer å bruke talespråket til å kommunisere og forklare religioner og livssyn, etikk og filosofi.» Ordet «forklare» kan, men må ikkje, vere det same som å gje noko ei rasjonell (bort)forklaring som er kritikk i trong tyding.

Vel så viktig er det at planen viser til opplæringslova og presiserer at undervisninga heilt allment skal vere «objektiv, kritisk og pluralistisk» (s. 2). I opplæringsplanen for Den norske kyrkja («Gud gir, vi deler», Kyrkjerådet 2010) er kritikk nemnd to gonger i samband med kyrkjelæra (ekklesiologien): «Barn og unge skal få kunnskap om og kjennskap til kyrkja dei høyrer til, inkludert eit kritisk perspektiv på tradisjonen og historia til kyrkja» (s. 17). I samband med misjonstenkinga blir det peika på at barn gjennom kunnskap om dette feltet «kan få hjelp til å rette eit kritisk blikk mot sin eigen kultur» (s. 31). I eit kritisk perspektiv står òg formuleringane om at ein skal lære om sant og viktig, det vondes problem, tilhøvet mellom tru og vitskap og mellom kristen tru og ulike religionar og livssyn (s. 16). Alle slike formuleringar verkar vere tenkt som referansar til tronge tydingar av kritikk.

Spørsmålet om kritikk i undervisningssamanhengar er likevel ikkje fullt ut svart på med dette. For ein kan òg seie at kritikk har ein langt meir grunnleggjande funksjon for læring, ja - som føresetnad for å lære.

\section{KRITIKK SOM FøRESETNAD FOR LERING}

Kritikk kan nemleg seiast å vere ein del av teorien om læring som omlæring som den tyske pedagogen Meyer-Drawe (1982) har peika på. Ho argumenterer for at når vi lærer, skjer det alltid som ei endring av det som var, anten det dreier seg om kunnskap eller dugleik (ferdigheit). Forsterkande læring er òg omlæring, vi kan det då på ein annan måte. Endringa er læringa, og læring er alltid ei om-læring. Ikkje noko er vel meir endrande enn dømmande kritikk. Kritikk 
i den tronge tydinga kan etablere det motsette, eller negativitet $i$ ei allmenn tyding. Det «negative» i denne samanhengen er då ikkje noko vi ikkje likar, men berre «noko anna» eller «det motsette». I denne teorien om læring som alltid «negativ» er kritikk positivt vurdert på eit grunnleggjande sett.

Men for betre å skjøne kva denne teorien om negativ læring tyder, kan vi igjen ty til hermeneutisk teori, og igjen er teorien om horisontar avgjerande. Førestellinga om horisontar kan vi føre tilbake til fenomenologiens grunnleggjar Edmund Husserl og studentane hans tidleg på 1900-talet i studiet. Han studerte det han kalla den naturlege innstillinga til livet og væren-i-verda (livsverda). Horisontomgrepet enda opp med å bli ein fenomenologisk grunnidé som viser til det allmenne skiljet mellom oppfatninga vår av nærvær og fråvær, om skiljet mellom det vi kan oppfatte direkte og det vi berre kan oppfatte indirekte. ${ }^{4} \AA$ utvide horisonten tyder som sagt ikkje å utvide sjølve delelina, men å flytte henne utover slik at vi oppfattar i st $ø$ rre grad direkte det som før berre var indirekte eller fråverande møtt, og såleis anonymt til stades. Teorien om fråværet som konstituerer nærværet, representerer ei innsikt i generell subjektivitet, og blir oppfatta som den viktigaste teoretiske nyskapinga frå Husserl si side (Sokolowski 2000). Dette hadde rett og slett ingen tenkt på før.

Gadamer fører denne teorien inn i teksttolkingsteorien og seier at forståing av teksten først oppstår når min og teksten sin horisont flyt saman (jf. Gadamer 1990, s. 31; jf. s. 270ff; Fuglseth 2006). Alle ord vi kan knyte til forståing, meining og forventning er sentrale i den filosofiske fenomenologien om livsverda, og dei kan alle førast saman i horisontomgrepet (Husserl 1960:44ff.; H. Kuhn 1968; van Peursen 1977; Gadamer 1990, s. 270ff; Rosen 1997). Horisontar kan i empiriske studiar skildrast som klassebestemte, $\emptyset$ konomiske, psykologiske, kulturelle, personlege o.l. Førforståing, før-kjennskap, tradisjonar, mønster, kategoriar vi har lært, er sjølve vilkåret for å forstå. Gamle, klassiske tekstar blir forståelege for oss av di dei har ei lang verknadshistorie (Gadamer 1990, s. 305) som kjem til oss gjennom den allmenne kulturen vi veks opp i.

Dette subjektive grepet, at vi må engasjere oss på eit vis eller bringe inn eigne horisontar for å forstå ein tekst, kan vi òg overføre på det å forstå andre menneske generelt (jf. ovanfor), men det er sjølvsagt ein del skilnader mellom sosiale og tekstlege møte, som Ricoeur peika på (1981; jf. 1988). Våre eigne horisontar er ikkje fastlagde som objektiverte og statiske tekstar, men endrar seg i møte med andre, og i dialog. Dette gjeld uavhengig av om vi er klar over kva for oppfatningar eller horisontar vi faktisk har, dei kan jo vere kulturelt bestemte og noko vi ikkje sjølve nødvendigvis er klar over.

Det viktigaste for teorien om læring som negativ læring eller omlæring ligg i

4 Vi føresteller oss til dømes at ei framside alltid har ei bakside, som Husserl peika på i arbeidet hans frå 1890-talet jf. boka Logische Untersuchungen publisert i 1900-01 (Husserl, jf. Husserliana 19, s. 399). 
at det i horisontomgrepet er bakt inn denne førestellinga om fråvær av noko, ein negativitet. Den synlege horisonten ligg til dømes mellom himmel og hav, men òg mellom det vi ser og det vi ikkje ser - som vi likevel oppfattar. Horisontlina ligg i denne tydinga mellom det positivt og det negativt gjevne. Gadamer (1990, s. 307, note 232) følgjer Helmut Kuhn (1968/1940) si tolking av filosofien frå Husserl om horisontar. Kuhn argumenterer for at det er tre grunnleggjande sider ved ein horisont og såleis forståing generelt, noko som òg er grunnlag for ein læringsteori:

1 Horisontutviding skjer ved at vi flyttar fokus.

2 Horisontar er avgjerande rammer for å etablere forståing.

3 Horisontar er alltid opne.

Når det gjeld det første punktet om horisontutviding ved å flytte fokus (1), viser dette til at når vi oppfattar noko, oppfattar vi aldri berre éin ting sjølv om auget berre har eitt fokus om gangen, resten av synsfeltet er uklårt. Horisont-omgrepet viser då, i analogi til dette, til den store krinsen av alle dei tinga vi kan kome til å oppfatte samstundes, anten dei er verkelege eller fiktive. «Ting» blir her brukt generelt, ikkje berre om konkrete gjenstandar. Ein lærar kan hjelpe elevar til å flytte fokus ved å peike på kritikk av det som før vart fokusert. Å utvide horisonten er òg å flytte fokus frå den eine tingen og sjå han i ein stadig større kontekst av ting, emne eller fenomen. Di større krins av tilknytingar, di betre forståing. $\AA$ flytte fokus på fenomenet vi arbeider med, t.d. frå lesing av heilage tekstar til historisk kritikk av desse, utvidar horisonten. Når det gjeld horisont som ramme (2), kan vi seie at rammer blir sett rundt det vi oppfattar. Horisonten hjelper oss å oppfatte ein ting som heil sjølv om vi berre ser litt av han, og det får oss til å sjå korleis konteksten påverkar oppfatninga av fenomenet. Vi lærer at det alltid kan vere andre kontekstar som gjev fenomenet nye tydingar. Når det gjeld opne horisontar (3), blir dette tydeleg når vi flyttar oss frå sentrum til ytterkanten av den store omkrinsen. Då dukkar det opp stadig nye horisontar. Grensene for omkrinsen flyttar seg, og vi overstig (transcenderer) stadig horisonten, utan at vi nokon gong skal tru at vi kjenner alle kontekstar. Men di fleire vi kjenner, di meir kan vi seie at vi veit og kan.

Kritikk, som negativ faktor, utvidar forståinga på alle desse måtane. Kritikk gjev dette blikket utanfrå som fører oss effektivt inn i nye hermeneutiske sirklar. Difor bør vi øve konkret på kritikk, t.d. ved å prøve haldningar (Embree 2013, s. 149ff). Det vi då øver på i skule og kyrkje, er sjølve menneskelivet (Brinkmann 2012, s. 170). Kritikk i trong tyding blir ei nødvendig grenseerfaring. Det same kan skje i samband med undersøkjande samtalar og grunngjeving av meiningar og haldningar rasjonelt i skulen, som hos Siegel $(1988,1997,2015)$ eller i filosofi med barn (Børresen og Malmhester 2003). Religionskritikk og kritikk av det 
sekulære vil òg begge vere nødvendige grenseerfaringar for barn som kjem til skule eller kyrkje med ein meir sekulær bakgrunn.

Horisontteorien kan såleis seiast å vere grunnlaget for teorien om læring som negativ eller som omlæring. Det er òg grunnlaget for teorien om korleis læring og erfaring generelt går i hermeneutiske sirklar eller spiralar: Kjennskap til heilskapen, den større forståinga, skjer gjennom kjennskap til delane, og delane forstår vi berre gjennom kjennskap til det heile. Ved heile tida å måtte gå gjennom omlæring, lærer vi. Det svarer til ein annan kjend danningsstrategi, å møte barn med den lærarhaldninga «som-om-dei-alt visste» (Oettingen 2011, s. 52ff). Her blir det ikkje sett på som så avgjerande at andre ikkje forstår alt vi som lærarar seier og gjer, det er vel så viktig at dei innser at det er noko dei ikkje forstår, men som dei kan kome til å forstå seinare, og sjølvsagt er det ingen lærar som har forstått alt eller som ikkje har noko å lære (ein lærer så lenge ein har elevar). Introduksjonen av nye ord har denne funksjonen. Spørsmål i klasserommet eller konfirmantundervisninga som er vanskelege for barn og unge å svare på, har ein viktig funksjon på denne måten. Å spørje inneheld denne negative funksjonen (her positivt vurdert). Dette gjeld òg innanfråkunnskap om religion for dei som ikkje har slike horisontar. Eit typisk trekk ved det pluraliserte samfunnet er at vi ikkje lenger kan vere sikre på kva som vil vere den negative erfaringa hjå andre. Om sekularisme er den dominerande horisont i samfunnet og hjå den einskilde, vil religiøse påstandar vere det som utvidar horisonten deira, det som verkar avklarande for kunnskapen og forståinga av det sekulære.

Men heller ikkje med denne avklaringa meiner eg at kritikkens plass i didaktisk arbeid er avklart. For ingenting i undervisninga kan fungere i eit målretta tomrom. Det er her diskusjonane om danningsidealet kjem inn. Diskusjonen er like gamal som institusjonen skule, og er ikkje mindre aktuell i dagens fleirkulturelle situasjon.

\section{KRITIKK I EIT OPE DANNINGSIDEAL MED BESTEMTE VERDIAR}

Den moderne pedagogikken som voks fram i Europa i kjølvatnet av den franske revolusjonen, var splitta i synet sitt på skulen. På den eine sida skal skulen ta vare på individet sin rett til å realisere seg sjølv, til fridom frå tradisjonar og nedervde tankar og gjeremål. På den andre sida skal han sjå til ønsket frå samfunnet om å ha informerte medborgarar som tar ansvar for andre, høyrer på og blir høyrt av andre. Vi finn ein radikal frigjeringstanke som danningsmål, kombinert med tanken om eit ansvar som gjer denne fridomen mogleg for alle. I dette ligg det eit paradoks: fridom treng ei viss form for tvang (Oettingen 2005). Paradokset går mellom anna ut på at det er ulogisk å fortelje nokon at dei ikkje skal høyre på det andre fortel dei, eller at oppseding til eit demokratisk sinnelag til ein viss grad er avhengig av udemokratiske verkemiddel (t.d. skuleplikt). 
Problemet, som er uttrykt i danningsparadokset, må finne ei løysing, no som før. Dette forsterkar seg sannsynlegvis med akselererande pluralisering og dobbelpluraliteten som vi ser i dag (jf. ovanfor).

Ei løysing på paradokset som byggjer på den klassiske danningstanken, er presentert av den før nemnde tyske pedagogen Dietrich Benner: all planlagt danning må vere samstundes open og lukka, noko han kallar eit «ikkje-affirmativ» eller ikkje-stadfestande danningsideal. Det er ikkje skulens oppgåve å drive danning i berre éi retning, så skulen må vere open gjennom den haldninga lærarane og andre viser i praksis. Vi kan såleis ikkje i dag stille med bestemte mål (telos) for danninga, eller operere med bestemming av identitetar, seier Benner. Danninga skal vere ikkje-teleologisk. Men skulen som institusjon og læraren i klasserommet må likevel stille med bestemte verdiar i undervisninga. Vi treng eit hierarkisk verdisystem, der nokre førestellingar er betre enn andre (Benner 2014). Undervisning i skule og kyrkjer o.l. skal vere open ved å vere ikkje-teleologisk, men lukka ved å operere med verdiar i eit hierarki. Denne tankegangen oppfattar eg som å vere i samsvar med A. Wrights kritiske religionspedagogikk (2004), som seier at undervisninga både skal vere både «anarkistisk», dvs. utan styring, og «arkistisk», dvs. med styring. Det er kanskje viktig å understreke dette i den seinmoderne perioden, med oppløysing av subjektivitetsomgrepet slik vi ser i den radikale hermeneutikken (jf. Gallagher 1992, s. 10). Skule kan såleis i seg sjølv seiast å vere eit dannande og ope prosjekt ved samstundes å vere eit kritisk prosjekt.

Den ikkje-affirmative danningsteorien til Benner har altså to prinsipp som må verke samstundes: læreplanane og læraren må på same tid vere ikkje-stadfestande og målretta, både open og lukka. $\AA$ finne ein balanse mellom desse to prinsippa i praktisk undervisning er viktig, og det er ein stadig tilbakevendande problematikk i læreplandiskusjonane.

Fagplanane i KRL/RLE/KRLE har heile tida, frå dei grunnleggjande ideane i «Identitet og dialog» og fram til revisjon i 2015, eigentleg følgt dette dobbelprinsippet, med ulike vektleggingar. Mange av diskusjonane om KRL/RLE/ KRLE-faget i dag dreier seg framleis om formuleringa «objektiv, kritisk og pluralistisk» (Opplæringslova, heilt tilbake til innføringa av L97, jf. Rundskriv F-003-98). Oppløysinga av den konfesjonelle undervisninga og den saklege orienteringa som denne endringa førte med seg, svarer godt til ideala i den moderne, ikkje-affirmative danningstanken. Den gamle føremålsparagrafen i norsk skule («gje elevane ei kristen og moralsk oppseding») kunne verte oppfatta som både hierarkisk og teleologisk, noko som er problematisk i den opne danningstanken. Den nye føremålsparagrafen frå 2009 har òg tydeleg eit hierarkisk verdisett når han seier at «[o]pplæringa skal byggje på grunnleggjande verdiar i kristen og humanistisk arv og tradisjon». Formuleringa «byggje på» er ikkje direkte 
teleologisk. Likevel finn vi andre teleologiske formuleringar i opplæringslova. I par. 1,1 6. ledd står det at: «[e]levane og lærlingane skal lære å tenkje kritisk og handle etisk og miljøbevisst.». Uttrykket «handle miljøbevisst» kan seiast å leggje klåre føringar for både lærarpraksisar og vurderingar av desse, og er såleis teleologisk, i strid med det opne danningsidealet. Men vi kan tenkje på det som ein verdi snarare enn som konkret identitet. Sitatet viser at $\emptyset v s t$ i hierarkiet ligg kritikken sjølv. I opplæringslova par. 1-1, 2. ledd finn vi òg verdiar høgt oppe i verdihierarkiet som «respekt for menneskeverdet og naturen, på åndsfridom, nestekjærleik, tilgjeving, likeverd og solidaritet».

Når det gjeld opplæringsplanane i Den norske kyrkja, stiller det seg litt annleis, men berre litt, for her er retning, telos, tydelegare i sjølve det formulerte føremålet for læringsarbeidet. Når kritikk likevel blir trekt inn, er det tydeleg at læreplanen i Den norske kyrkja òg ligg innanfor det vi kan kalle ikkje-affirmativ læringsideal.

Sterk og absolutt kritikk kan likevel vere ueigna i undervisning. I den grad kritikken blir skeptisistisk (ingenting er sant) eller absolutistisk (éi løysing er sann), vil han vere problematisk i lys av det ikkje-affirmative danningsidealet. I ein fleirkulturell skule treng vi ein plural didaktikk som heller ikkje er relativistisk (alt er like sant). Det vi treng, er ei lærarhaldning som seier at noko kan vere sant (jf. Gravem 2004, 2005, 2006 og 2007). Denne lærarhaldninga som Gravem har argumentert for, kan vi kalle open skeptisisme eller «possibilisme», og er i tråd med eit ope danningssyn.

\section{KRITISERE FOR $\AA$ FORSTA}

Eg har argumentert for at vi kan kombinere poenget frå kritisk teori eller kritisk sosiologi og den kritiske didaktikken med poenget frå Gadamer om hermeneutikkens forrang. Kritikk er ikkje eit eintydig ord, og vi kan skilje mellom kritikk som skildrande (vid tyding) og kritikk som dømmande (trong tyding). I den vide tydinga ligg det ikkje berre kritikk av religion, men òg kritikk av ikkje-religion eller sekulære livssyn, kritikk av kritikken, kritikk av metakritikken osb. Skiljet mellom kritikk i vid og trong tyding er avgjerande for å sjå korleis vi kan bruke kritikk i undervisning, i skule som i kyrkje. Kritikk føreset likevel tolking og forståing, altså hermeneutikk, men alt er ikkje sagt med det. Vi kan møte kritikk før vi har forstått. Læring som forståing er tufta på at vi møter noko anna eller noko negativt, nye erfaringar som til dømes kritikk. Hermeneutikk og kritikk er slik sett ikkje motstandarar (antitetiske), men utfyller kvarandre (komplementære). Denne løysinga på kritikk-problemet kan kallast dialektisk ved at motsetnader utløyser ny forståing. Å øve på kritikk, er å øve på å forstå. Om vi skal forstå godt, må vi møte kritikkar og øve oss på å kritisere. 
I den tronge tydinga av ordet vil likevel kriteriet for vurderinga spele inn og leggje ein dempar på einsidig kritisk undervisning i ein fleirkulturell skule der religionsfridom samstundes skal vere eit berande element. Problemet er at denne dømande kritikken kan bli absolutistisk, noko som er i strid med den plurale haldninga i open skeptisisme. Ein einsidig kritikk utan til dømes kritikk av kritikken, vil vere i strid mot det ikkje-affirmative idealet.

\section{LitTERATUR}

Apel, K.-O., Bormann, C., Buner, R., Gadamer, H. G., Giegel, H. J. og Habermas, J. (red.) (1971). Hermeneutik und Ideologiekritik. Frankfurt am Main: Suhrkamp.

Apel, K.-O. (1992). «The hermeneutic dimension of social science and its normative foundation. $\gg$ Man and World, 25, 247-270.

Apel, K.-O. og Øfsti, A. (2008). The Public sphere. Essays in honour of Karl-Otto Apel. [Siggerud]: Res Publica.

Benner, D., Göstemeyer, K.-F., og Sladek, H. (red.). (1999). Bildung und Kritik. Studien zum Gebrauch von Kritik im Umgang mit Bildungszielen und -problemen. Weinheim: Deutscher Studienverlag.

Benner, D. (2008). Bildungstheorie und Bildungsforschung. Grundlagenreflexionen und Anwendungsfelder. Paderborn: Ferdinand Schöningh.

Benner, D. (2015). Allgemeine Pädagogik. Eine systematisch-problemgeshichtliche Einführung in die Grundstruktur pädagogischen Denkens und Handelns (8. utg.). Weinheim: Juventa.

Berger, P. L. (2014). The many altars of modernity. Toward a paradigm for religion in a pluralist age. Boston: de Gruyter.

Betti, Emilio. Allgemeine Auslegungslehre Als Methodik der Geisteswissenschaften. Mohr/ Siebeck, 1967.

Bratberg, $\emptyset$. (2017). Tekstanalyse for samfunnsvitere. Oslo: Cappelen Damm Akademisk.

Brinkmann, M. (2012). Pädagogische Übung. Praxis und Theorie einer elementaren Lernform. Paderborn: Schöningh.

B $\emptyset$ rresen, B., \& Malmhester, B. (2003). La barna filosofere. Kristiansand: Høyskoleforlaget.

Critchley, S. (2001). Continental Philosophy. A very short introduction. Oxford: Oxford University Press.

Dawkins, R. (2008). The God Delusion. Boston: Houghton Mifflin Harcourt.

Embree, L. (2013). Refleksiv analyse. Ei første innføring i fenomenologisk gransking (K. Fuglseth, oms.). Trondheim: Akademika forlag.

Foucault, M. (2013). Qu'est-ce que la critique? La culture de soi. Paris: Vrin.

Fuglseth, K. (2006). «Horisontsamansmelting som metode. Eit døme frå historiskkritisk bibelforsking.» I M. Brekke (red.), § begripe teksten. Om grep og begrep $i$ tekstanalyse (s. 141-158). Kristiansand: Høyskoleforlaget. 
Fuglseth, K. (2016). «Orienteringas bakside. 'Indirekte undervisning' og mangelen på engasjement, interesse og motivasjon.» Prismet (2), 79-85.

Føllesdal, D. og Walløe, L. (2000). Argumentasjonsteori, språk og vitenskapsfilosofi. Oslo: Universitetsforlaget.

Gadamer, H. G. (1971). «Replik.» I K.-O. Apel, C. Bormann, R. Bubner, H. G. Gadamer, H. J. Giegel og J. Habermas (red.), Hermeneutik und Ideologiekritik (s. 283-318). Frankfurt am Main: Suhrkamp.

Gadamer, H. G. (1990). Wahrheit und Methode; Grundzüge einer philosophischen Hermeneutik (Taschenbuchausgabe 199). Tübingen: Mohr.

Gadamer, H.-G. (1993). «Die Universalität des hermeneutischen Problems.» Gesammelte Werke 2 (Taschenbuchausgabe 1999, s. 219-223). Tübingen: Mohr.

Gadamer, H.-G. (2010). Sannhet og metode. Grunntrekk $i$ en filosofisk hermeneutikk (L. Holm-Hansen, oms.). Oslo: Pax.

Gallagher, S. (1992). Hermeneutics and education. New York: State University of New York Press.

Gravem, P. (2004). KRL - et fag for alle? KRL-faget som svar på utfordringer i en flerkulturell enhetsskole. Vallset: Oplandske bokforlag.

Gravem, P. (2005). «Religions- og livssynsundervisning innenfor rammene av menneskerettighetene.» Norsk teologisk tidsskrift, 102(2), 67-89.

Gravem, P. (2006). «KRL-faget og menneskerettighetene. Et bidrag til en tverrfaglig debatt.» Norsk teologisk tidsskrift (1), 48-59.

Gravem, P. (2007). "Religions- og livssynsundervisning i en flerkulturell skole.» Nordisk tidsskrift for menneskerettigheter, 25(1), 65-68.

Habermas, J. (1971) «Zu Gadamers <Wahrheit und Methode>.» (1971). I K.-O. Apel, C. Bormann, R. Bubner, H. G. Gadamer, H. J. Giegel og J. Habermas (red.), Hermeneutik und Ideologiekritik (s. 45-56). Frankfurt am Main: Suhrkamp.

Hellesnes, J. (2014). Meining? Religionskritikk og filosofi hos Nietzsche og Garborg. Oslo: Samlaget.

Klafki, W. (2002). Schultehorie, Schulforschung und Schulentwicklung im politisch-gesellschaftlichen Kontext. Ausgewählte Studien. Weinheim: Beltz.

Krogh, T. (2009). Hermeneutikk. Om å forstå og fortolke. Oslo: Gyldendal akademisk.

Kubac, R. (2013). Vergebliche Zusammenhänge? Erkenntnispolitische Relationierungen von Bildung und Kritik. Paderborn: Ferdiand Schöningh.

Kyrkjerådet. (2010). Gud gir - vi deler. Plan for trusopplaring i Den norske kyrkja. Oslo: Kyrkjerådet, Den norske kyrkja.

Meyer-Drawe, K. (1982). «Lernen als Umlernen. Zur Negativität des Lernprozesses.» I W. Lippitz og K. Meyer-Drawe (red.), Lernen und seine Horizonte. Phänomenologische Konzeptionen menschlichen Lernens - didaktische Konsequenzen (s. 19-41). Frankfurt am Main: Scriptor. 
NOU (2014). Elevenes læring i fremtidens skole. Et kunnskapsgrunnlag (NoU 2014:7). Oslo: Kunnskapsdepartementet.

NOU (2015). Fremtidens skole. Fornyelse av fag og kompetanser (NoU 2015:8). Oslo: Kunnskapsdepartementet.

Oettingen, A. von (2005). Det pædagogiske paradoks. En grundstudie i almen pæedagogik. Århus: Klim.

Oettingen, A. von (2011). Almœen pædagogik. Pœdagogikens grundlaggende spørsmål. København: Gyldendals lærerbibliotek.

Rittelmeyer, C. og Parmentier, M. (2001). Einführung in die pädagogische Hermeneutik. Darmstadt: Wissenschaftliche Buchgesellschaft.

Ricoeur, P. (1981). Hermeneutics and the human sciences. Essays on language, Action and interpretation. Cambridge University Press: Cambridge.

Ricoeur, P. (1988). Från text til handling. Stockholm: Brutus Östlings Bokförlag.

Schweitzer, F. (2014). Interreligiöse Bildung. Religiöse Vielfalt als religionspädagogische Herausforderung und Chance. Gütersloh: Gütersloher Verlagshaus.

Seebohm, T. M. (2004). Hermeneutics. Method and methodology. Dordrecht: Kluwer.

Siegel, H. (1988). Educating reason. Rationality, critical thinking, and education. New York: Routledge.

Siegel, H. (1997). Rationality redeemed? Further dialogues on an educatinal ideal. New York: Routledge.

Siegel, H. (2015). «New work on critical thinking. Comments on Frimannsson, Holma og Ritola.» Studier i pæedagogisk filosofi, 4(1), 55-62.

Staudigl, M. (red.) (2008). Alfred Schütz und die Hermeneutik. Konstanz: UVK.

$\emptyset$ fsti, A. (1980). Vitenskapsteori og transcendentalfilosofi. En kritisk kommentar til Føllesdal og Walløe: «Argumentasjonsteori og vitenskapsfilosofi». Trondheim: Tapir. 